\title{
ANALISIS PELAKSANAAN MANAJEMEN PEMBELAJARAN \\ MATA PELAJARAN PENDIDIKAN AGAMA ISLAM DI SMP 4 KUDUS TAHUN PELAJARAN 2015/2016
}

\author{
Moh. Akhsanulkhaq \\ Dinas Pendidikan Kabupaten Kudus \\ akhsanulkhaq.mohammad@gmail.com
}

\begin{abstract}
Abstrak
Penelitian ini bertujuan untuk mendeskripsikan implementasi manajemen pembelajaran Pendidikan Agama Islam; problematika pembelajaran Pendidikan Agama Islam dan solusinya; output dari pelaksanaan manajemen pembelajaran Pendidikan Agama Islam di SMP 4 Kudus. Subjek penelitian ini adalah Kepala Sekolah, Wakaur Kurikulum, Komite Sekolah, Guru PAI dan peserta didik. Teknik pengumpulan data menggunakan metode observasi, wawancara, dokumentasi dan triangulasi. Hasil penelitian menunjukkan bahwa: (1) implementasi manajemen pembelajaran Pendidikan Agama Islam terlaksana cukup baik yang mencakup perencanaan, pelaksanaan dan evaluasi/penilaian. (2) Beberapa permasalahan yang terjadi dalam pembelajaran Pendidikan Agama Islam dapat diatasi dengan cukup baik dengan solusi yang telah diajalankan; (3) Output pelaksanaan manajemen pembelajaran PAI terlihat cukup baik dilihat dari prestasi belajar Pendidikan Agama Islam yang cukup memuaskan.
\end{abstract}

Kata Kunci: Pelaksanaan Manajemen Pembelajaran dan Pendidikan Agama Islam

\begin{abstract}
This study aimed to describe the implementation of Islamic education learning management; problematics of Islamic education and learning solutions; the output from the learning management implementation of Islamic Education in SMP 4 Kudus. This research subject is the principal, deputy head of affairs curriculum, school committee, teachers and learners. Data collection techniques using the method of observation, interviews, documentation and triangulation. The results showed that: (1) the implementation of Islamic education learning management done well enough that include planning, implementation and evaluation/assessment. (2) Some of the problems that occur in the learning of Islamic education can be overcome quite well with the solutions that have been diajalankan; (3) Output implementation of Islamic education learning management looks pretty good views of the learning achievement of Islamic Religious Education, satisfactory.
\end{abstract}

Keywords: Implementation of Learning Management and Islamic Education.

\section{A. Pendahuluan}

Keberhasilan pendidikan dan efektivitas Proses Belajar Mengajar (PBM) dipengaruhi oleh beberapa faktor, salah satunya dipengaruhi oleh faktor manajemen pembelajaran. Bahkan manajemen pembelajaran memiliki fungsi sebagai alat untuk mencapai tujuan terciptanya suatu pembelajaran yang menghasilkan interaksi guru 
QUALITY

Volume 5, Nomor 1, 2017: 190-209

dengan peserta didik yang efektif dan efesien. Menurut Hadari Nawawi menegaskan bahwa pada dasarnya sekolah dan kelas diselenggarakan untuk memenuhi kebutuhan masyarakat dalam mendidik peserta didik, yang tidak harus didewasakan dari aspek intelektualnya saja, akan tetapi dalam aspek kepribadiannya, (Nawawi, 2004).

Manajemen pembelajaran merupakan segala usaha pengaturan Proses Belajar Mengajar (PBM) dalam rangka tercapainya tujuan pembelajaran yang dapat menjadikan setiap anak di kelas bekerja dengan tertib sehingga tercapai tujuan pengajaran secara efektif dan efisien, (Arikunto, 2005). Pembelajaran tidak hanya terbatas pada kegiatan yang dilakukan oleh guru dengan konsep mengajarnya, melainkan pembelajaran mencakup pada semua kegiatan yang mempunyai pengaruh langsung pada Proses Belajar Mengajar (PBM) seperti halnya televisi, film, slide, gambar dan sebagainya, (Mulyasa, 2013). Oleh karena itu, setiap akan melakukan pembelajaran, guru wajib melakukan perencanaan. Dengan adanya perencanaan yang baik, maka pelaksanaan pembelajaran akan dapat berjalan lancar, terarah, dan sistematis. Hal ini dapat tercapai karena kompetensi dasar, materi pokok, indikator, pengalaman belajar, alokasi waktu, sumber, langkah-langkah pembelajaran, dan rencana penilaian telah dirumuskan dengan baik dan digambarkan dengan jelas, (Wahyuni \& Ibrahim, 2012).

Untuk itu fungsi dari manajemen pembelajaran adalah segala usaha pengaturan proses belajar mengajar (PBM) dalam rangka tercapainya proses belajar mengajar yang efektif dan efisien. Sebab pembelajaran yang efektif dapat menjadi tolok ukur keberhasilan pembelajaran, jika proses pembelajarannya efektif maka tujuan pembelajaranpun dapat tercapai dengan mudah. Efektivitas pembelajaran dapat tercipta melalui pembelajaran yang dilakukan guru di kelas baik dari segi guru, peserta didik, lingkungan, dan metode mengajar guru, (Bafadal, 2004). Salah satu faktor terpenting dalam meningkatkan efektivitas pembelajaran di kelas yaitu dengan menciptakan suasana belajar senyaman mungkin agar pembelajaran dapat berlangsung secara optimal. Fungsi-fungsi manajemen menjadi bagian penting dalam proses belajar mengajar terkait dengan efektivitas belajar mengajar peserta didik dengan maksud tercapainya tujuan pembelajaran, (Arikunto, 2005). 
QUALITY

Volume 5, Nomor 1, 2017: 190-209

Selama ini, pendidikan agama Islam masih dinilai kurang bisa mengubah pengetahuan agama yang kognitif menjadi "makna" dan "nilai" atau kurang mendorong penjiwaan terhadap nilai-nilai keagamaan yang perlu diinternalisasikan dalam diri peserta didik. Dengan kata lain, pendidikan agama Islam selama ini lebih menekankan pada aspek knowing dan doing dan belum banyak mengarah ke aspek being, yakni bagaimana peserta didik menjalani hidup sesuai dengan ajaran Islam dan nilai-nilai agama Islam yang diketahui (knowing), (Arikunto, 2005: 123). Dalam kenyataannya yang ada di lapangan pendidikan agama Islam mutunya masih rentan, karena belum mencapai target secara memadai khususnya di sekolah umum. Selain realita tersebut, ada asumsi bahwa dalam kehidupan sekolah sering dilihat adanya para guru yang dapat dikatakan tidak berhasil dalam mengajar. Indikator dari ketidakberhasilan guru adalah prestasi atau hasil belajar peserta didik yang rendah, tidak sesuai dengan batas ukuran yang ditentukan. Kegagalan ini bukan hanya ketidakberhasilan guru dalam mengajarkan tugasnya yaitu menguasai materi bidang studi ketika penyampaian saja, tetapi ketidaktahuan guru dalam manajemen pembelajaran. Hal ini berakibat pada ketidak efektifan pembelajaran khususnya pendidikan agama Islam sehingga kualitas peserta didik menurun, (Arikunto, 2000).

SMP 4 Kudus merupakan salah satu lembaga pendidikan di kota Kudus, maka dalam program sekolahnya SMP 4 Kudus terus mengembangkan diri untuk meningkatkan mutu pendidikan. Dalam upaya meningkatkan mutu pendidikan di SMP 4 Kudus telah mengupayakan berbagai cara dengan mengutamakan proses pembelajaran yang seefektif mungkin yaitu pembelajaran dengan menggunakan media pembelajaran yang variatif didukung teknologi yang berkembang saat ini. Upaya meningkatkan mutu pendidikan dalam pembelajaran di SMP 4 Kudus khususnya dalam pembelajaran Pendidikan Agama Islam (PAI) pada observasi awal terlihat sudah mengimplementasikan manajemen pembelajaran tersebut dengan tujuan mencapai hasil yang optimal, seperti dalam kegiatan Proses Belajar Mengajar (PBM) sudah menerapkan metode-metode yang cocok untuk materi pembelajaran pada saat itu. Suasana kelaspun tidak sunyi, dan komunikasi peserta didik antar gurupun terlihat harmonis baik di dalam kelas maupun luar kelas.

\section{Kajian Teori}


QUALITY

Volume 5, Nomor 1, 2017: 190-209

Menurut Usman (2002) dalam bukunya yang berjudul Konteks Implementasi Berbasis Kurikulum mengemukakan pendapatnya mengenai implementasi atau pelaksanaan adalah bermuara pada aktivitas, aksi, tindakan, atau adanya mekanisme suatu sistem. Implementasi bukan sekedar aktivitas, tetapi suatu kegiatan yang terencana dan untuk mencapai tujuan kegiatan. Pengertian implementasi yang dikemukakan tersebut, dapat dikatakan bahwa implementasi adalah bukan hanya sekedar aktivitas, tetapi suatu kegiatan yang terencana dan dilakukan secara sungguh-sungguh berdasarkan acuan norma tertentu untuk mencapai tujuan kegiatan. Oleh karena itu implementasi tidak berdiri sendiri tetapi dipengaruhi oleh objek berikutnya.

Menurut Setiawan (2004) dalam bukunya yang berjudul Implementasi dalam Birokrasi Pembangunan mengemukakan mengenai implementasi atau pelaksanaan adalah perluasan aktivitas yang saling menyesuaikan proses interaksi antara tujuan dan tindakan untuk mencapainya serta memerlukan jaringan pelaksana, birokrasi yang efektif. Pengertian implementasi tersebut, dapat dikatakan bahwa implementasi yaitu merupakan proses untuk melaksanakan sebuah ide, proses atau seperangkat aktivitas baru dengan harapan orang lain dapat menerima dan melakukan penyesuaian dalam tubuh birokrasi demi terciptanya suatu tujuan yang bisa tercapai dengan jaringan pelaksana yang bisa dipercaya.

Berbagai pengertian di atas memperlihatkan bahwa implementasi bermuara pada aktivitas, adanya aksi, tindakan, atau mekanisme suatu sistem. Ungkapan mekanisme mengandung arti bahwa implementasi bukan sekadar aktivitas, tetapi suatu kegiatan yang terencana dan dilakukan secara sungguhsungguh berdasarkan acuan norma tertentu untuk mencapai tujuan kegiatan. Oleh karena itu, implementasi tidak berdiri sendiri tetapi dipengaruhi oleh obyek berikutnya yaitu manajemen. Menurut Sudarwan dan Danim, (2010) mengartikan manajemen adalah sebuah proses yang khas, yang terdiri atas tindakan-tindakan perencanaan, pengorganisasian, menggerakkan, dan pengawasan, yang dilakukan untuk menentukan serta mencapai sasaran-sasaran 
QUALITY

Volume 5, Nomor 1, 2017: 190-209

yang telah ditetapkan melalui pemanfaatan sumber daya manusia serta sumbersumber lain untuk mencapai tujuan tertentu.

Manajemen pembelajaran terdiri dari dua kata, yaitu manajemen dan pembelajaran. Secara bahasa (etimologi) manajemen berasal dari kata kerja "to manage" yang berarti mengatur, (Hikmat, 2009). Adapun menurut istilah (terminologi) terdapat banyak pendapat mengenai pengertian manajemen salah satunya menurut George R. Terry, dalam Hasibuan (2007) mengartikan manajemen adalah suatu proses khas yang terdiri atas tindakan-tindakan perncanaan, pengorganisasian, penggerakan, dan pengendalian untuk menentukan serta mencapai tujuan melalui pemanfaatan SDM dan sumber daya lainnya.

Manajemen pembelajaran dapat didefinisikan sebagai usaha mengelola lingkungan belajar dengan sengaja agar seseorang belajar berprilaku tertentu dalam kondisi tertentu. Jadi, menajemen pembelajaran terbatas pada satu unsur manajemen sekolah saja, sedangkan manajemen pendidikan meliputi seluruh komponen system pendidikan, bahkan bisa menjangkau sistem yang lebih luas dan besar secara regional, nasional, bahkan internasional, (Mulyasa, 2012).

Berdasarkan pengertian pembelajaran dan manajemen pembelajaran diatas dapat disimpulkan bahwa konsep manajemen pembelajaran sebagai proses mengelola yang meliputi kegiatan perencanaan, pengorganisasian, pengendalian (pengarahan) dan pengevaluasian kegiatan yang berkaitan dengan proses membelajarkan peserta didik (orang yang belajar) dengan mengikutsertakan berbagai faktor di dalamnya guna mencapai tujuan. Beberapa bagian terpenting dari manajemen pembelajaran tersebut antara lain: (a) penciptaan lingkungan belajar; (b) mengajar dan melatihkan harapan kepada peserta didik; (c) meningkatkan aktivitas belajar; (d) meningkatkan disiplin peserta didik. Rancangan tugas ajar diperlukan pula dalam penyusunan materi dalam wilayah psikomotrik, rancangan tugas ajar wilayah kognitif, serta rancangan tugas ajar wilayah afektif.

Pendidikan dalam Islam lebih banyak dikenal dengan menggunakan istilah al-tarbiyah, al-ta'lim, al-ta'dib dan al-riyadhah. Setiap terminologi 
QUALITY

Volume 5, Nomor 1, 2017: 190-209

tersebut mempunyai makna yang berbeda satu sama lain, karena perbedaan teks dan konteks kalimatnya dan pendidikan Islam memiliki beberapa karakteristik yang berbeda dengan pengertian pendidikan secara umum. Pendidikan adalah segala usaha yang dilakukan untuk mendidik manusia sehingga dapat tumbuh dan berkembang sehingga memiliki kemampuan sebagaimana mestinya, (Muchtar, 2005).

Pendidikan Agama Islam (PAI) merupakan usaha sadar dan terencana untuk menyiapkan peserta didik dalam meyakini, memahami, dan mengamalkan Islam melalui kegiatan bimbingan, pengajaran dan atau latihan. Pendidikan Agama Islam yang pada hakekatnya merupakan sebuah proses itu, dalam perkembangannya juga dimaksud sebagai rumpun mata pelajaran yang diajarkan di sekolah maupun perguruan tinggi, (Nazarudin, 2007).

Dari beberapa definisi di atas dapat diambil kesimpulan bahwa Pendidikan Agama Islam ialah merupakan usaha sadar yang dilakukan pendidik dalam rangka mempersiapkan peserta didik untuk meyakini, memahami, dan mengamalkan ajaran islam melalui kegiatan bimbingan, pengajaran atau pelatihan yang telah dikumpulkan untuk mencapai tujuan yang telah ditetapkan. Dan dapat dilihat pula perbedaan-perbedaan antara pendidikan secara umum dengan pendidikan Islam. Perbedaan utama yang paling menonjol adalah bahwa pendidikan Islam bukan hanya mementingkan pembentukan pribadi untuk kebahagiaan dunia, tetapi juga untuk kebahagiaan akhirat. Selain itu pendidikan Islam berusaha membentuk pribadi yang bernafaskan ajaran-ajaran Islam dan merupakan rangkaian usaha membimbing, mengarahkan dan melatih anak didik menuju terbentuknya sikap dan tingkah laku yang sesuai dengan petunjuk dan ajaran Islam.

\section{Metode Penelitian}

Jenis penelitian ini adalah penelitian lapangan (field research), yakni penelitian yang dilakukan dalam situasi alamiah akan tetapi didahului oleh semacam intervensi (campur tangan) dari fihak peneliti. Intervensi ini dimaksudkan agar fenomena yang dikehendaki oleh peneliti dapat segera tampak dan diamati. Dengan demikian terjadi semacam kendali atau kontrol 
QUALITY

Volume 5, Nomor 1, 2017: 190-209

parsial terhadap situasi di lapangan, (Azwar, 205). Pendekatan penelitian yang digunakan adalah kualitatif deskriptif karena penelitian ini menghasilkan kesimpulan berupa data yang menggambarkan secara rinci, bukan data yang berupa angka-angka. Hal ini karena pendekatan kualitatif sebagai prosedur penelitian yang menghasilkan data deskriptif berupa kata-kata tertulis atau lisan dari orang-orang dan perilaku yang diamati, (Moleong, 2008). Sesuai dengan penelitian ini, nantinya peneliti akan mencari data-data deskriptif tentang pelaksanaan manajemen pembelajaran PAI di SMP 4 Kudus.

Penelitian ini mengambil lokasi di SMP 4 Kudus, letaknya berada di pinggir perkotaan tepatnya di Jl. Dewi Sartika No. 14 Desa Singocandi Kecamatan Kota Kabupaten Kudus. Penelitian ini subjek penelitiannya adalah Kepala Sekolah, Wakaur Kurikulum, Komite Sekolah, Guru PAI dan peserta didik. Dengan sumber data tersebut diharapkan didapat informasi yang akurat mengenai pelaksanaan manajemen pembelajaran PAI di SMP 4 Kudus.

Teknik pengumpulan data dilakukan dengan pengamatan (observasi), wawancara mendalam (in depth interview), dokumentasi dan triangulasi. Tempat observasi dalam penelitian ini adalah di SMP 4 Kudus. Pelaku yang diteliti dalam observasi ini adalah pihak yang berkompeten dalam Manajemen Pendidikan Agama Islam yang meliputi Kepala Sekolah, Waka Kurikulum, peserta didik dan yang paling utama adalah Guru mata pelajaran Pendidikan Agama Islam. Adapun wawancara yang diajukan kepada subyek, secara garis besar akan mengungkap dengan beberapa pertanyaan dari yang kurang mendalam (pheriperal) sampai pada pertanyaan yang teramat mendalam (probing) dalam rangka menggali, mengklarifikasi/mencari kesadaran kritis dalam mencari penjelasan yang bertujuan berupaya menfokuskan kembali jika dalam wawancara terjadi pembiasan tentang bagaimana gambaran manajemen pembelajaran Pendidikan Agama Islam di SMP 4 Kudus. Sedangkan dokumentasi digunakan untuk memperoleh data tambahan yang terkait kegiatan proses belajar mengajar, perangkat pembelajaran, serta gambaran umum SMP 4 Kudus yang meliputi daftar guru dan karyawan, daftar peserta didik, struktur organisasi dan sarana prasarana. Teknik terakhir yaitu triangulasi dilakukan 
QUALITY

Volume 5, Nomor 1, 2017: 190-209

dengan menggunakan sumber lain yaitu membandingkan dan mengecek kembali derajat kepercayaan suatu informasi yang diperoleh melalui waktu dan data yang berbeda.

Tahap penelitian tentang manajemen pembelajaran Pendidikan Agama Islam (PAI) di SMP 4 Kudus. Dibagi menjadi empat tahapan, yaitu: tahap pralapangan, tahap pekerjaan lapangan, tahap analisis data dan tahap penyelesaian. Dalam penelitian kualitatif, kriteria utama terhadap data hasil penelitian adalah valid, reliabel, dan obyektif. Sebagaimana Sugiono (2006) menyebutkan bahwa Uji keabsahan data dalam penelitian kualitatif meliputi: Uji Credibility (Validitas internal), transferability (validitas eksternal), dependability (reliabilitas), dan confirmability (objektivitas). Teknik analisis data yang digunakan dalam penelitian ini adalah model analisis interaktif. Teknik analisis data tersebut sesuai dengan yang dikemukakan oleh Milles dan Huberman, (Sugiono, 2006). Model analisis interaktif adalah suatu analisis data kualitatif yang terdiri dari tiga alur kegiatan, yaitu: reduksi data, penyajian data, dan penarikan kesimpulan atau verifikasi. Aktivitas penarikan kesimpulan berbentuk interaksi dengan proses pengumpulan data sebagai proses siklus antara tahaptahap tersebut. Teknik analisis data tersebut dilakukan bersamaan dengan proses pengumpulan data di lapangan.

\section{B. Pembahasan}

\section{Implementasi Manajemen Pembelajaran PAI di SMP 4 Kudus}

\section{a. Perencanaan Pembelajaran PAI}

Sebelum melaksanakan pembelajaran guru PAI membuat perencanaan perangkat pembelajaran terlebih dahulu. Mulai dari RPP, media pembelajaran, buku guru dan buku peserta didik. Hal ini dilakukan untuk mempermudah dan sebagai pedoman ketika mengajar di kelas, dan juga mempersiapkan kondisi psikis peserta didik ketika mengawali kegiatan belajar mengajar. Perencanaan merupakan salah satu fungsi dari manajemen pembelajaran, selain pelaksanaan dan evaluasi. Usman dalam Triwiyanto menyatakan bahwa perencanaan pembelajaran adalah kegiatan yang 
dilakukan masa yang akan datang untuk mencapai tujuan pembelajaran. Perencanaan pembelajaran mengandung unsur-unsur: sejumlah kegiatan yang ditetapkan sebelumnya; adanya proses; hasil yang ingin dicapai; dan menyangkut masa depan dalam waktu tertentu, (Triwiyanto, 2015).

Peran penting Kepala Sekolah dalam mengawal perencanaan pembelajaran PAI yang dilakukan guru di sekolah adalah dengan memastikan bahwa semua guru yang akan melaksanakan tugas mengajar harus membuat perencanaan pembelajaran yang meliputi program tahunan, program semester, silabus RPP, media pembelajaran atau alat bantu. Jurnal kelas, absensi peserta didik dan daftar nilai. Untuk itu manajemen pembelajaran merupakan keterampilan yang harus dimiliki oleh seorang guru PAI dalam merumuskan, memahami, mendiagnosis, dan kemampuan bertindak menuju perbaikan suasana kelas yang dinamis dengan tujuan agar proses belajar mengajar berlangsung secara efektif.

Berkaitan dengan perencanaan pembelajaran Pendidikan Agama Islam di SMP 4 Kudus, dalam membuat perencanaan pembelajaran guru PAI mendapat kejelasan dari MGMP PAI tentang bagaimana seharusnya format perencanaan pembelajaran yang dirumuskan dalam silabus. Format silabus yang disusun meliputi satuan pendidikan, mata pelajaran, kelas, SK, KD, materi pembelajaran, kegiatan pembelajaran, penilaian, alokasi waktu, dan sumber belajar. Adapun format rencana pelaksanaan pembelajaran yang disusun oleh guru PAI tersebut secara umum meliputi: satuan pendidikan, mata pelajaran, kelas/semester, alokasi waktu, standar kompetensi, kompetensi dasar, indikator, tujuan, materi, metode, media dan sumber, langkah-langkah dan penilaian (evaluasi). Jadi, sebelum melaksanakan pembelajaran Pendidikan Agama Islam di SMP 4 Kudus menyiapkan perangkat pembelajaran terlebih dahulu supaya pembelajaran dapat berjalan efektif dan efisien. Dengan adanya perencanaan pembelajaran, dapat menjadi acuan dan dasar pelaksanaan pembelajaran di dalam kelas sehingga proses pembelajaran dapat berjalan secara sistematis.

\section{b. Pelaksanaan Pembelajaran PAI}


QUALITY

Volume 5, Nomor 1, 2017: 190-209

Pelaksanaan pembelajaran Pendidikan Agama Islam, guru PAI mendesain Rencana Pelaksanaan Pembelajaran (RPP) sedemikian rupa sesuai dengan tujuan pembelajaran termasuk pendekatan, metode dan tekniknya. Kemudian untuk mewujudkan pembelajaran Pendidikan Agama Islam yang efektif dan efisien, diperlukan kreativitas guru PAI dalam mendesain pembelajaran sesuai tujuan pembelajaran terutama mendesain strategi pembelajaran yaitu penerapan pendekatan, metode dan teknik. Sebagaimana salah satu guru PAI di SMP 4 dalam pembelajaran menggunakan pendekatan pembelajaran kooperatif dengan metode problem solving dan terkait tekniknya menerapkan pemberian tugas, diskusi, tanya jawab dan ceramah. Proses pembelajaran Pendidikan Agama Islam yang efektif dan efisien hendaknya mempergunakan berbagai jenis metode mengajar secara bergantian atau bervariasi. Tugas guru PAI ialah memilih berbagai metode yang tepat sesuai materi yang diajarkan untuk menciptakan proses belajar mengajar.

Mengenai pengembangan materi, guru PAI mengidentifikasi materi pelajaran Pendidikan Agama Islam dengan mempertimbangkan potensi peserta didik, manfaat bagi perkembangan peserta didik, alokasi waktu dan lain-lain serta tuntasnya materi pelajaran tergantung sedikit banyak materi yang disampaikan dan disesuaikan dengan situasi dan kondisi kelas. Berkaitan dengan media pembelajaran yang digunakan guru PAI di SMP 4 Kudus sudah bisa dikatakan baik. Dalam menyampaikan pembelajaran Pendidikan Agama Islam guru PAI sangat terbantu dengan adanya LCD proyektor. Melalui LCD guru dapat dengan mudah menampilkan materi maupun menayangkan video pembelajaran Pendidikan Agama Islam.

Pada pembelajaran Pendidikan Agama Islam, pemilihan pendekatan, metode dan teknik tersebut diorientasikan pada pembiasaan dan pelatihan yang dibantu oleh seorang guru PAI. Upaya pembiasaan yang dilakukan guru PAI dalam memulai pembelajaran dengan berdoa \pm 5 menit kemudian kami mengajak peserta didik membaca asmaul husna \pm 10 menit, kemudian doa di akhir pembelajaran. Dalam hal ibadah sholat dhuha, sholat dzuhur, 
QUALITY

Volume 5, Nomor 1, 2017: 190-209

guru membuat daftar sholat setiap minggu. Selain itu ada pengembangan SMS shalat dari guru PAI terhadap peserta didik. Hal tersebut bertujuan untuk mengecek bagaimana tingkat keimanan dan tingkat kemauan beribadah peserta didik.

Pengembangan program pembelajaran Pendidikan Agama Islam lainnya dalam bentuk kegiatan ekstrakurikuler di SMP 4 Kudus yang mendukung kegiatan pembelajaran pendidikan Agama Islam adalah Tartil Baca Tulis Al-Qur'an (BTA), tilawah. Hal ini diadakan dengan tujuan meningkatkan kemampuan peserta didik dalam membaca dan menulis AlQuran dan meningkatkan keterampilan peserta didik dalam tilawatil Qur'an dan kalau bisa meningkatkan prestasi non akademik peserta didik dalam kegiatan tilawah atau bisa juara dalam mengikuti kegiatan lomba yang diadakan setiap tahunnya, selain itu ada juga rebana untuk mengembangkan bakat peserta didik di bidang seni.

Materi yang diajarkan pada ekstrakurikuler Tartil BTA, tilawah dikembangkan sesuai dengan kompetensi yang diajarkan di SMP 4 Kudus. Jika dilihat pada SKL (Standar Kompetensi Lulusan) Pendidikan Agama Islam di SMP 4 Kudus aspek Al-Qur'an, ternyata menekankan pada penguasaan ilmu Tajwid, maka penyusunan silabus ini banyak ditekankan pada ilmu tajwid. Sedangkan pengembangannya sesekali peserta didik diajari qiro'ah, tentu saja jika nanti anak-anak sudah banyak yang lancar membaca dan fasih dalam bacaannya, maka peserta didik bisa ditugaskan untuk mengisi acara-acara peringatan hari besar keagamaan Islam yang biasanya dibuka dengan pembacaan ayat suci Al-Qur'an.

\section{c. Evaluasi Pembelajaran PAI}

Tahap akhir dalam pelaksanaan pembelajaran Pendidikan Agama Islam adalah dengan melakukan evaluasi. Kegiatan evaluasi pembelajaran Pendidikan Agama Islam di SMP 4 Kudus sudah berjalan dengan efektif, mulai dari perencanaan, pelaksanaan sampai pada mengelola data. Guru PAI dalam kegiatan evaluasi senantiasa melakukan perencanaan, pelaksanaan dan mengolah data dalam setiap pembelajaran. Sehingga dapat mengetahui 
QUALITY

Volume 5, Nomor 1, 2017: 190-209

tercapai tidaknya tujuan pembelajaran Pendidikan Agama Islam serta kualitas proses belajar mengajar yang telah dilaksanakan.

Kegiatan evaluasi pembelajaran Pendidikan Agama Islam dilakukan sebagai bentuk perbaikan sistem penilaian peserta didik dan metode yang digunakan dalam pembelajaran PAI berikutnya, maka dari itu perencanaan evaluasi juga merumuskan tujuan penilaian, mengidentifikasi hasil belajar, dan kemudian membuat soal untuk peserta didik yang diberikan di akhir pembelajaran. Evaluasi yang dilakukan oleh guru PAI sudah mencakup seluruh aspek penilaian, yaitu kognitif, afektif dan psikomotorik.

Kemudian saat guru PAI melaksanakan evaluasi formatif, guru menggunakan metode tanya jawab untuk mereview sejauhmana peserta didik memahami materi yang disampaikan. Saat evaluasi berlangsung peserta didik sangat aktif dalam menanggapi pertanyaan-pertanyaan yang diberikan oleh guru. Meskipun ada beberapa peserta didik yang kurang begitu memahami dengan materi yang disampaikan tetapi proses evaluasi berlangsung dengan baik. Selain itu proses penilaian PAI tidak hanya menilai ketuntasan materi di dalam kelas saja, tetapi juga menilai penerapan dari materi-materi tersebut dalam perilaku sehari-hari.

Setiap guru yang akan membuat tes dalam rangka evaluasi dengan menggunakan pedoman penyusunan tes dengan memperhatikan tingkat kesukaran peserta didik atas soal yang telah diberikan kepada peserta didik. Selain itu guru juga harus menentukan standar kelulusan terhadap mata pelajaran PAI dengan didukung penilaian secara observasi dalam setiap proses mengajar. Guru PAI di SMP 4 Kudus dalam pelaksanaan evaluasi sering menggunakan penilaian formatif, penilaian tersebut dimaksudkan untuk memantau kemajuan belajar peserta didik selama proses belajar mengajar berlangsung, untuk memberikan umpan balik bagi penyempurnaan program pembelajaran. Akan tetapi guru juga tidak mengesampingkan penilaian sumatif, dimana dalam penilaian ini menggunakan tes tulis untuk lebih mengembangkan pola berfikir sehingga peserta didik dapat kreatif mengembangkan bahasanya. 
Dari pemaparan di atas hasil evaluasi dapat digunakan untuk mengetahui tingkat pemahaman peserta didik terhadap materi yang telah disampaikan oleh guru dan guru dapat membantu peserta didik dalam pencapaian tujuan pembelajaran dalam materi tersebut. Kegiatan evaluasi dapat dilihat dalam penilaian yang telah didesain dalam RPP yang telah disusun. Ketentuan mengenai penilaian hasil pembelajaran Pendidikan Agama Islam, diantaranya: Pertama, penilaian hasil pembelajaran menggunakan berbagai teknik penilaian sesuai dengan kompetensi dasar yang harus dikuasai. Kedua, teknik penilaian dapat berupa tes tertulis, observasi, tes praktik, dan penugasan perseorangan atau kelompok. Ketiga, teknik penilaian observasi secara individual sekurang-kurangnya dilaksanakan satu kali dalam satu semester.

\section{Problematika Pembelajaran PAI dan Solusi Mengatasi Problematika}

\section{Tersebut di SMP 4 Kudus}

Problematika pelaksanaan pembelajaran Pendidikan Agama Islam di SMP 4 Kudus dapat dilihat pada uraian berikut:

a. Faktor waktu. Faktor waktu merupakan kendala yang sangat besar dalam proses pembelajaran Pendidikan Agama Islam dikarenakan waktu yang sangat minim, dalam satu minggu hanya dua jam pelajaran, satu tatap muka.

b. Faktor konsentrasi anak. Karena setiap anak mempunyai karakteristik yang berbeda-beda, diantaranya ada anak yang langsung konsentrasi dan siap menerima pelajaran dan ada pula anak yang belum siap belajar dan masih terlihat ribut di dalam kelas.

c. Faktor kemampuan dasar BTA kurang memuaskan. Diantara hal yang kurang memuaskan adalah masih banyak ditemui kesalahan peserta didik dalam membaca Al-Qur'an, misalnya ada beberapa peserta didik yang masih kurang lancar tajwidnya seperti terbata-bata dalam membaca ayat AlQur'an, belum mampu mempraktikkan bacaan dengan benar, demikian juga dengan menulis Al-Qur'an.

d. Faktor minimnya tenaga pengajar PAI. Selama ini di SMP 4 Kudus hanya memiliki dua guru PAI. Sehingga dalam penerapannya guru PAI merasa 
QUALITY

Volume 5, Nomor 1, 2017: 190-209

kerepotan dalam mengatasinya. Fakta di lapangan yang dijumpai di sekolah adalah terkadang kurang disiplinnya guru, terutama masalah disiplin guru masuk ke dalam kelas pada saat kegiatan pembelajaran di kelas.

e. Faktor kurang obyektifnya penilaian pada aspek afektif. Hal ini berkaitan erat dengan pembuatan tujuan pembelajaran yang benar-benar efektif dan operasional yang hampir mustahil. Karena itu pemberian nilai afektif didasarkan atas kebijaksanaan guru PAI masing-masing. Dengan demikian tidak ada standar yang baku seperti halnya aspek kognitif dan psikomotorik.

f. Faktor perbedaan latar belakang orang tua peserta didik. Karena pendidikan yang pertama diperoleh adalah pendidikan didalam keluarga. Jadi apabila orang tua peserta didik kurang dalam pemahaman dan penghayatan agamanya atau awam akan pendidikan agama maka sangat mempengaruhi peserta didik dalam pembelajaran Pendidikan Agama Islam di sekolahnya.

Untuk mengatasi problematika pelaksanaan pendidikan agama Islam di sekolah dapat diupayakan beberapa solusi yang diharapkan mampu meyelesaikan permasalahan yang dihadapi sebagaimana yang akan diuraikan sebagai berikut:

a. Untuk mengatasi problem minimnya waktu pelaksanaan pembelajaran Pendidikan Agama Islam di sekolah yaitu dengan meningkatkan kedisiplinan guru PAI.

b. Solusi yang dilakukan guru PAI untuk menghadapi problematika kendala konsentrasi anak dalam menerima pelajaran adalah mencari perhatian khusus terhadap anak agar saat proses pembelajaran mereka benar-benar siap menerima pelajaran.

c. Terkait dengan kemampuan dasar anak yang berbeda dalam membaca dan menulis Al-Qur'an, maka guru PAI membuat kelas khusus ditunjang dengan tutor sebaya. Selain itu peserta didik diarahkan dan diwajibkan mengikuti kegiatan ekstrakurikuler tartil.

d. Solusi yang dilakukan selama ini yaitu dengan memanfaatkan guru-guru yang ada yang ditugaskan menjadi guru piket dan juga ada guru tambahan pembimbing kegiatan ekstrakurikuler PAI. 
QUALITY

Volume 5, Nomor 1, 2017: 190-209

e. Agar penilaian berjalan efektif dan memiliki validitas yang tinggi, perlu disiapkan lembaran pengamatan yang berisi rumusan-rumusan yang menjabarkan tingkah laku peserta didik yang dapat ditunjukkan dalam tindakan dan dapat diamati oleh guru.

f. Solusi yang dilakukan guru PAI yaitu dengan memberikan pengertian akan pentingnya Pendidikan Agama Islam kepada orang tua peserta didik melalui pertemuan wali murid dan ikut berperan khusus untuk mengawasi mereka di rumah. Dengan begitu mungkin sedikit demi sedikit oran tua akan tahu betapa pentingnya Pendidikan Agama Islam untuk anak-anak.

\section{Output Pelaksanaan Manajemen Pembelajaran PAI di SMP 4 Kudus}

Untuk mengetahui keberhasilan guru dalam mengajar maka guru melaksanakan penilaian, penilaian ini biasanya dilaksanakan diakhir pembelajaran dilaksanakan melalui 3 (tiga) aspek yaitu kognitif, afektif dan psikomotorik adapun penilaian yang melalui aspek kognitif dengan ulangan tertulis, penilaian yang melalui aspek afektif dengan penanaman sikap dan penilaian yang melalui aspek psikomotorik dengan praktek dan ada juga penilaian yang rutin setiap 3 bulan sekali yang disebut penilaian tengah semester dan 6 bulan sekali disebut penilaian semesteran. Penilaian pada dasarnya bertujuan untuk mengetahui perkembangan hasil belajar peserta didik dan hasil pelaksanaan kegiatan pembelajaran Pendidikan Agama Islam.

Untuk itu, sekolah mempunyai peranan yang penting dalam membantu peserta didik mencapai tugas perkembangannya. Sehubungan dengan hal ini, sekolah seyogyanya berupaya menciptakan iklim yang kondusif, atau kondisi yang dapat memfasilitasi peserta didik untuk mencapai tugas perkembangannya. Tugas-tugas perkembangan peserta didik menyangkut aspek-aspek kematangan dalam berinteraksi sosial, kematangan personal, kematangan dalam mencapai filsafat hidup, dan kematangan dalam beriman dan bertaqwa kepada Tuhan Yang Maha Esa. Salah satu mata pelajaran yang melaksanakan fungsi tersebut adalah mata pelajaran Pendidikan Agama Islam.

Prestasi belajar sebagai hasil yang dicapai oleh individu setelah mengalami suatu proses belajar dalam jangka tertentu, hasil belajar Pendidikan 
QUALITY

Volume 5, Nomor 1, 2017: 190-209

Agama Islam (PAI) peserta didik mencakup ranah kognitif, ranah afektif dan ranah psikomotorik. SMP 4 Kudus sebagai lembaga pendidikan umum telah menunjukkan hasil yang positif dengan adanya berbagai prestasi PAI yang telah diraih oleh peserta didik. Prestasi tersebut dicapai atas koordinasi yang baik antara kepala sekolah, guru, peserta didik dan komponen lain yang mendukung. Dengan peningkatan prestasi belajar PAI peserta didik di SMP 4 Kudus dapat mempertahankan eksistensi lembaga pendidikan ini.

Prestasi belajar Pendidikan Agama Islam di SMP 4 Kudus sudah cukup baik yang ditandai dengan nilai pelajaran PAI peserta didik sudah memenuhi target KKM; Penerapan amalan agama sudah dilaksanakan dengan baik, dengan adanya pembiasaan yang dilaksanakan SMP 4 Kudus; Peserta didik SMP 4 Kudus mendapatkan juara III di tahun 2015 dan tahun 2016 dalam perlombaan Musabaqoh Tilawatil Qur'an (MTQ) yang diadakan di tingkat Kabupaten.

\section{Simpulan}

Berdasarkan uraian di atas, maka ada tiga kesimpulan yang dapat disajikan dalam penelitian ini.

Pertama, Implementasi manajemen pembelajaran Pendidikan Agama Islam di SMP 4 Kudus, dapat dilihat dari perencanaan pembelajaran, pelaksanaan pembelajaran dan evaluasi pembelajaran Pendidikan Agama Islam. (1) perencanaan pembelajaran Pendidikan Agama Islam di SMP 4 Kudus, dilakukan dengan membuat perencanaan pembelajaran guru PAI mendapat kejelasan dari MGMP PAI tentang bagaimana seharusnya format perencanaan pembelajaran yang dirumuskan dalam silabus. Format silabus yang disusun sesuai format umumnya. Adapun format rencana pelaksanaan pembelajaran (RPP) juga yang disusun oleh guru PAI tersebut secara umum, (2) pelaksanaan pembelajaran Pendidikan Agama Islam, dilaksanakan dengan pemilihan pendekatan, metode dan teknik yang diorientasikan pada pembiasaan dan pelatihan. Upaya pembiasaan yang dilakukan guru PAI dalam memulai pembelajaran dengan berdoa \pm 5 menit kemudian kami mengajak peserta didik membaca asmaul husna \pm 10 menit, kemudian doa di akhir pembelajaran. Dalam hal ibadah sholat dhuha, sholat dzuhur, guru membuat daftar sholat setiap 


\section{QUALITY}

Volume 5, Nomor 1, 2017: 190-209

minggu. Selain itu ada pengembangan SMS shalat dari guru PAI terhadap peserta didik. Adapun Pengembangan program pembelajaran PAI pada kegiatan ekstrakurikuler meliputi: tartil, BTA (Baca Tulis Al-Qur'an), tilawah, dan rebana, (3) Kegiatan evaluasi pembelajaran guru PAI di SMP 4 Kudus berusaha mengefektifkan kegiatan evaluasinya mulai dari perencanaan, pelaksanaan sampai mengelola data. Ketentuan mengenai penilaian hasil pembelajaran Pendidikan Agama Islam, diantaranya: penilaian hasil pembelajaran menggunakan berbagai teknik penilaian sesuai dengan kompetensi dasar yang harus dikuasai. Teknik penilaian dapat berupa tes tertulis, observasi, tes praktik, dan penugasan perseorangan atau kelompok. Teknik penilaian observasi secara individual sekurang-kurangnya dilaksanakan satu kali dalam satu semester.

Kedua; Problematika yang terjadi dalam pembelajaran Pendidikan Agama Islam (PAI) di SMP 4 Kudus, diantaranya adalah (1) faktor waktu, (2) faktor konsentrasi anak, (3) faktor kemampuan dasar membaca dan menulis al-Qur'an kurang memuaskan, (4) faktor minimnya tenaga pengajar PAI, (5) faktor kurang obyektifnya penilaian pada aspek afektif, dan (6) faktor perbedaan latar belakang orang tua peserta didik. Untuk mengatasi problematika pelaksanaan pembelajaran pendidikan agama Islam di sekolah dapat diupayakan beberapa solusi yang diharapkan mampu meyelesaikan permasalahan yang dihadapi, yaitu: (1) untuk mengatasi problem minimnya waktu pelaksanaan pembelajaran Pendidikan Agama Islam di sekolah yaitu dengan meningkatkan kedisiplinan guru PAI, (2) solusi yang dilakukan guru PAI untuk menghadapi kondala konsentrasi anak adalah mencari perhatian khusus terhadap anak agar saat proses pembelajaran mereka benar-benar siap menerima pelajaran. (3) terkait dengan kemampuan dasar anak yang berbeda dalam membaca dan menulis Al-Qur'an, maka guru PAI membuat kelas khusus bagi peserta didik yang belum mampu membaca dan menulis Al-Qur'an untuk dibina lebih lanjut secara kelompok-kelompok ditunjang dengan tutor sebaya dari peserta didik, (4) solusi yang dilakukan dalam mengatasi minimnya guru PAI selama ini yaitu dengan memanfaatkan guru yang ada yang ditugaskan menjadi guru piket dan juga ada guru tambahan pembimbing kegiatan ekstrakurikuler PAI, (5) Penilaian aspek afektif dilakukan melalui angket lebih praktis dan menghemat 


\section{QUALITY}

Volume 5, Nomor 1, 2017: 190-209

waktu serta tenaga. Kemudian dengan wawancara, guru dapat memperoleh masukan langsung sehingga memperoleh keterangan lengkap. Terakhir menggunakan skala penilaian untuk mengukur sikap peserta didik, (6) upaya mengatasi perbedaan latar belakang orang tua peserta didik yaitu dengan memberikan pengertian akan pentingnya Pendidikan Agama Islam kepada orang tua peserta didik melalui pertemuan wali murid dan ikut berperan khusus untuk mengawasi mereka di rumah.

Ketiga; Output pelaksanaan manajemen pembelajaran Pendidikan Agama Islam (PAI) di SMP 4 Kudus dapat dilihat dari kemampuan guru dalam melaksanakan manajemen pembelajaran mata pelajaran PAI dapat membawa dampak positif terhadap peningkatan mutu pendidikan di sekolah. Maka dari itu, untuk mendukung situasi pembelajaran dapat berjalan lancar dan nyaman, guru PAI dalam manajemen pembelajaran dengan memperhatikan perbedaan individu seperti membantu peserta didik yang belum tuntas dari KKM dengan mengadakan jam tambahan belajar dan mengadakan remedial dan bagi peserta didik yang sudah tuntas dari KKM, guru PAI mengadakan pengayaan dengan cara memberikan soalsoal latihan. SMP 4 Kudus sebagai lembaga pendidikan umum telah menunjukkan hasil yang positif dengan adanya berbagai prestasi PAI yang telah diraih oleh peserta didik. Prestasi belajar Pendidikan Agama Islam di SMP 4 Kudus ditandai dengan nilai pelajaran PAI peserta didik sudah memenuhi target KKM; Penerapan amalan agama sudah dilaksanakan dengan baik, dengan adanya pembiasaan yang dilaksanakan SMP 4 Kudus; Peserta didik SMP 4 Kudus mendapatkan juara III di tahun 2015 dan tahun 2016 dalam perlombaan Musabaqoh Tilawatil Qur'an (MTQ) yang diadakan di tingkat Kabupaten.

Menindaklanjuti simpulan yang diperoleh, maka hal-hal yang disarankan dalam penelitian ini yaitu (1) Kepada Kepala Sekolah, hendaknya senantiasa memberikan kontribusi terhadap peningkatan kompetensi guru, dan pada gilirannya dapat membawa efek terhadap peningkatan mutu pendidikan di sekolah. (2) Kepada guru PAI, hendaknya senantiasa membuat perencanaan kegiatan belajar mengajar, melaksanakan kegiatan yang direncanakan dan melakukan penilaian terhadap hasil dari proses belajar mengajar. Selain itu dalam manajemen pembelajaran mata 


\section{QUALITY}

Volume 5, Nomor 1, 2017: 190-209

pelajaran Pendidikan Agama Islam yang telah dilaksanakan agar senantiasa dijaga dengan sebaik-baiknya dan dilaksanakan seoptimal mungkin. (3) Kepada peserta didik, diharapkan dapat menambah semangat belajar mereka terutama dalam mengikuti pembelajaran Pendidikan Agama Islam dengan baik sehingga nantinya dapat menyerap ilmu agama yang diberikan guru PAI dan dapat mengamalkannya dalam kehidupan sehari-hari dengan benar.

\section{DAFTAR PUSTAKA}

E Mulyasa, (2012). Manajemen Berbasis Sekolah, Konsep, Strategi, dan Implementasi, PT. Remaja Rosdakarya, Bandung.

---------,(2013). Manajemen dan Kepemimpinan Kepala Sekolah, Jakarta: Bumi Aksara.

Guntur Setiawan, (2004). Implementasi dalam Birokrasi Pembangunan, Remaja Rosdakarya, Bandung.

Hadari Nawawi, (2004) Organisasi Sekolah dan Pengelolaaan Kelas sebagai Lembaga Pendidikan, Haji Masagung, Jakarta.

Hasibuan, (2007). Manajemen; Dasar, Pengertian, dan Masalahal, PT. Bumi Aksara, Jakarta.

Heri Jauhari Muchtar, (2005). Fiqih Pendidikan, Remaja Rosdakarya, Bandung.

Hikmat, (2009). Manajemen Pendidikan, Pustaka Setia, Bandung.

Ibrahim Bafadal, (2004). Manajemen Perlengkapan Sekolah Teori dan Aplikasinya, Bumi Aksara, Jakarta.

Lexy J. Moleong (2008). Metode Penelitian Kualitatif, PT. Remaja Rosdakarya, Bandung.

Nazarudin, (2007). Manajemen Pembelajaran: Implementasi Konsep, Karakteristik dan Metodologi Pendidikan Agama Islam di Sekolah Umum, Teras, Yogyakarta.

Nurdin Usman, (2002). Konteks Implementasi Berbasis Kurikulum, PT. Raja Grafindo Persada, Jakarta.

Saifuddin Azwar, (2005). Metode Penelitian, Pustaka Pelajar, Yogyakarta.

Sri Wahyuni dan Abd. Syukur Ibrahim, (2012). Perencanaan Pembelajaran Bahasa Berkarakter, PT. Refika Aditama, Bandung.

Sudarwan Danim dan Yunan Danim, (2010). Administrasi Sekolah dan Manajemen Kelas, CV. Pustaka Setia, Bandung. 
QUALITY

Volume 5, Nomor 1, 2017: 190-209

Sugiyono, (2012). Metode Penelitian Pendidikan (Pendekatan. Kuantitatif, Kualitatif, dan R\&D), Alfabeta, Bandung, 2012.

Suharsimi Arikunto, (2000). Manajemen Pengajaran secara Manusiawi, PT. Rineka Cipta, Jakarta.

---------, (2005). Pengelolaan Kelas dan Siswa Sebuah Pendekatan Evaluatif, PT. Raja Grafindo Persada, Jakarta.

Teguh Triwiyanto, (2015). Manajemen Kurikulum dan Pembelajaran, Bumi Aksara, Jakarta. 
